\title{
Reproductive potential in a case of Mosaic Turners syndrome with 46XY karyotype
}

\author{
Geetha D. Balsarkar, Rachana D. Dalmia, Namita N. Raut*
}

Department of Obstetrics and Gynecology, Nowrosjee Wadia Hospital, Mumbai, Maharashtra, India

Received: 20 October 2019

Accepted: 19 November 2019

\section{* Correspondence:}

Dr. Namita N. Raut,

E-mail: namitaraut87@gmail.com

Copyright: (c) the author(s), publisher and licensee Medip Academy. This is an open-access article distributed under the terms of the Creative Commons Attribution Non-Commercial License, which permits unrestricted non-commercial use, distribution, and reproduction in any medium, provided the original work is properly cited.

\begin{abstract}
This article describes a case of 18year-old-female who presented with primary amenorrhea, phenotypic features of Turners syndrome, which was confirmed later by Karyotype to have mosaic $45 \mathrm{XO}(8) / 46 \mathrm{XY}(22)$. She had delayed puberty and proved (hormonally) to have ovarian failure, with absent Mullerian structures (radiologically and laparoscopy).
\end{abstract}

Keywords: Fish, Karyotype, Mosaic turners, Mullerian agenesis, Primary amenorrhea

\section{INTRODUCTION}

Turner's syndrome (TS) is one of the most common sex chromosomal disorder, affecting one in 2000 live-born females. ${ }^{1}$ Forty-five\% of patients were associated with the classical monosomic form $(45, \mathrm{XO})$, while the remaining are various mosaic forms..$^{2-4}$ The severity of clinical manifestation is in part related to the type of chromosomal abnormalities, the time at which chromosomal disjunction occurred and the proportion of compromised cells in each tissue. ${ }^{5}$ We report a rare case of a 18 year-old girl who presented with primary amenorrhea. She was found to have phenotypic features of Turner syndrome, and ovarian failure with absent Mullerian structures.

\section{CASE REPORT}

An 18-year-old female presented to gynaecology OPD at tertiary care centre with primary amenorrhea. Her parents' marriage was not consanguineous and she was a full-term normal delivery and all of her siblings were healthy individuals. Her height was $140 \mathrm{~cm}$ and weight $36 \mathrm{~kg}$. She had phenotypic features of Turners syndrome in the form of webbed neck, low set ears, bilateral epicanthic folds and cubitus valgus. Her breast and pubic hair development were Tanners stage 1. Her external genitalia were of normal female phenotype. Examination of cardiovascular, respiratory and neurological system was normal with normal haematological and biochemical parameters. Her Fsh was $121.97 \mathrm{mIU} / \mathrm{mL}$ and Lh 26 $\mathrm{mIU} / \mathrm{mL}$ suggestive of ovarian failure. Tsh was 16.32 $\mathrm{uIU} / \mathrm{ml}$ raised with normal $\mathrm{T} 3$ and $\mathrm{T} 4$ and anti Tpo antibodies negative. Ultrasonography of abdomen and pelvis showed extremely hypoplastic uterus and ovaries. Echocardiography was normal. Karyotyping by G banding on peripheral blood showed $\operatorname{mos} 45 \mathrm{XO}(8) / 46 \mathrm{XY}(22)$. Patient was posted for examination under anaesthesia with diagnostic laparoscopy sos gonadal biopsy in view of risk of gonadoblastoma. On examination vagina was normal. Intraoperative there was evidence of extremely hypoplastic uterus (Figure 1) with bilateral streak ovaries (Figure 2) and as they did not appear pathological, gonadal biopsy was not taken. Futhur management of patient was done in the form of cyclical combined low dose Oc pills and calcium and vitamin D supplementation. Patient was also started on thyroxin 
hormone and counseled regarding her condition. Patient was asked to keep 6 monthly follow up and ultrasound examination in view of risk of gonadoblastoma.

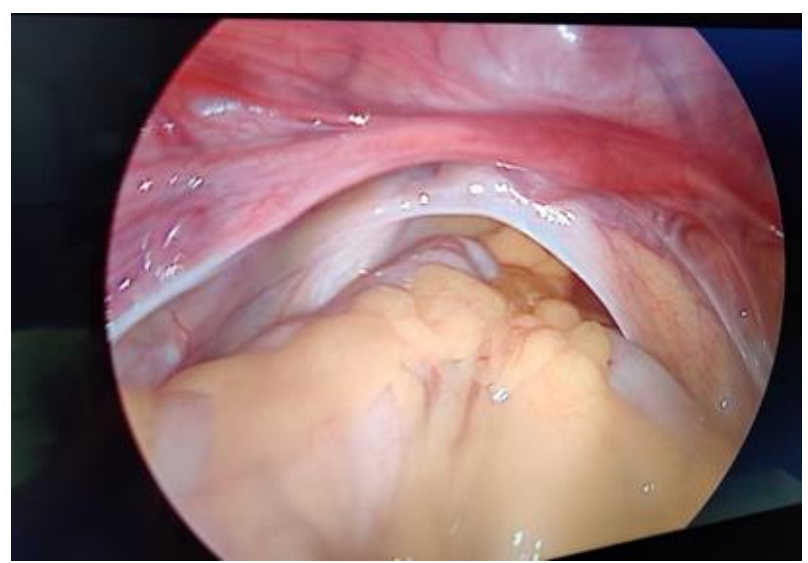

Figure 1: Laparoscopic view hypoplastic uterus.

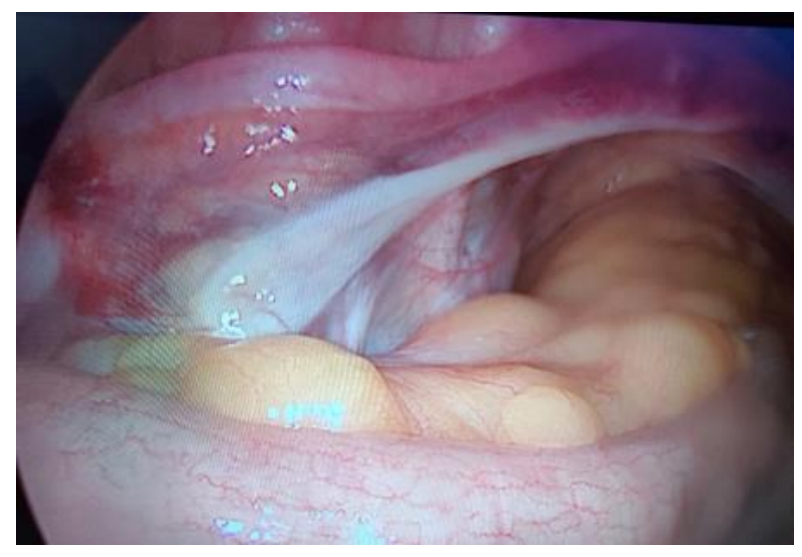

Figure 2: Laparoscopic view streak ovary.

\section{DISCUSSION}

Turner syndrome is one of the most common sex chromosomal disorders, affecting 1 in 2000 live births females. It is characterized by short stature, cubits valgus, webbed neck, nail dysplasia, shield-like chest, widely placed nipples, lymphedema of hands and feet, low set ears, genus valgus, horse-shoe kidney, and congenital heart disease and the most common of which is coarctation of aorta. Other clinical features include streak ovaries that leads to primary amenorrhea or premature ovarian failure. The ovaries usually develop normally at first, but the egg cells die prematurely and most of the ovarian tissue degenerates. Premature ovarian failure is confirmed by failure in the progress of puberty and primary amenorrhea which was supported by hormonal studies of low estradiol and very high gonadotrophins levels and was confirmed by ultrasonography and laparoscopy. Turner syndrome is associated with multiple chromosome abnormalities including 45,X and $45, \mathrm{X} / 46, \mathrm{XX}$ and $45, \mathrm{X} / 47, \mathrm{XXX}$ and $45, \mathrm{X} / 46, \mathrm{XY}$. The $45, X / 46, X Y$ genotype accounts for approximately 10 $12 \%$ of cases of Turner syndrome. ${ }^{6}$ In a report of 76 prenatally diagnosed cases of 45,X/46,XY mosaicism, 75 had male appearing external genitalia and only one had female genitalia. ${ }^{7}$ In a series of 27 postnatally diagnosed cases of $45, \mathrm{X} / 46, \mathrm{XY}$ mosaicism, 18 were male (11 with mixed gonadal dysgenesis) and 9 had Turner syndrome. ${ }^{8}$ Turner syndrome with 45,X/46,XY low-level mosaicism may not be detected on standard karyotype and FISH analysis of larger numbers of cells can be useful for diagnosis.

The American College of Medical Genetics (ACMG) provides guidelines for karyotyping procedure specific to Turner syndrome. The College recommends karyotyping a minimum of 30 cells due to the high incidence of mosaicism, unless mosaicism is encountered within the first 20 cells. When there is a high clinical suspicion of Turner syndrome in a patient with a 46,XX karyotype, cytogenetic study of a second tissue type (such as skin biopsy for cell culture or buccal smear for FISH) is advised. Additionally, given the risk of gonadoblastoma with occult $\mathrm{Y}$ chromosome mosaicism, the ACMG recommends 200 cell FISH analysis to probe for the $\mathrm{X}$ and $\mathrm{Y}$ centromeres when 30-cell karyotype results in a nonmosaic 45,X karyotype. ${ }^{9}$

Women with Turner syndrome who possess $\mathrm{Y}$ chromosome material have an increased risk of germ cell tumors such as gonadoblastoma and dysgerminoma. A national cohort study that included 211 of these patients estimated that, by age 25 , the cumulative risk of gonadoblastoma is $7.9 \%$ (95\% CI 3.1-19.0). ${ }^{10}$ Although rates of gonadoblastoma in Turner syndrome patients with $\mathrm{Y}$ chromosome material vary by study from as low as $4 \%$ to as high as $60 \%$, current evidence suggests that the rate is approximately $10 \%$. Prophylactic gonadectomy is recommended at the time of diagnosis for patients with Turner syndrome and $\mathrm{Y}$ chromosome material such as 45,X/46,XY mosaicism. ${ }^{11}$ Turner syndrome patients with any genotype should undergo standard testing and treatment for cardiovascular, renal, metabolic, endocrine, vision, hearing, and bone mineral density abnormalities. If premature ovarian failure is diagnosed, hormone replacement therapy is indicated until the typical age of menopause to induce puberty and secondary sexual characteristics, stimulate uterine growth, and prevent bone loss. It is generally recommended to begin treatment with low-dose E2 (3-7 $\mu \mathrm{g}$ /day of transdermal E2 or 0.25 mg oral E2 per day) at age 11 or 12 and incrementally increase the dose to adult doses (50-150 $\mu \mathrm{g} /$ day of transdermal E2 or 2-4 mg oral E2 per day) over 2 to 3 years. A progestin is added once breakthrough bleeding occurs or 2 years after E2 is begun to decrease the risk of endometrial hyperplasia. Progestin can be administered orally in a cyclic pattern with E2, orally continuously with E2, or in the form of a progestin containing intrauterine device. ${ }^{12}$ Successful pregnancy outcomes have occurred in patients with $45, \mathrm{X} / 46, \mathrm{XY}$ mosaicism as well as 46,XY gonadal dysgenesis following oocyte donation and in vitro fertilization, although most of the reported cases were delivered by cesarean section. ${ }^{13,14}$ 
However in this case as uterus is extremely hypoplastic surrogacy is the only option.

\section{CONCLUSION}

In summary future fertility is an important consideration for patients with Turner syndrome. Accurate and early diagnosis of 45,X/46,XY mosaicism can allow for counselling about reproductive potential and pursuing pregnancy with in vitro fertilization with donor egg and/or gestational surrogacy and also early diagnosis will help to tackle the risk of gonadoblastoma in these patients.

Funding: No funding sources

Conflict of interest: None declared

Ethical approval: No required

\section{REFERENCES}

1. Gravholt CH, Juuls N, Aeraa RW, Hansen J. Prenatal and post-natal prevalence of Turners syndrome: a registry study. BMJ. 1996;312(7022):16-21.

2. Mansoury EL, Barrenas M, Bryman ML, Hanson I, Larsson C. Chromosomal mosaicism mitigates stigmata and cardiovascular risk factors in Turners syndrome. Clin Endocrinol. 2007;66(5):744-51.

3. Venkateshwari A, Srimanjari K, Srilekha A, Begum A, Sujatha M, Sunitha T, et al. 45X/47XXX/46XX Karyotype in a female with Turner'syndrome Indian J Hum Genet. 2012;18(2):246-9.

4. Saenger P, Wikland KA, Conway GS, Davenport M, Gravholt $\mathrm{CH}$. Recommendations for the diagnosis and management of Turner syndrome $\mathrm{J}$ Clin Endocrinol Metal. 2001;86(7):3061-9.

5. Elamparidhi P, Kumar RR, Sivaranjinie S, Sibhithran R. Mullerian Agenesis Associated with Turner's Syndrome J Clin Diagn Res. 2017;11(2):TD01TD02.

6. Gravholt $\mathrm{CH}$, Andersen NH, Conway GS. Clinical practice guidelines for the care of girls and women with Turner syndrome: proceedings from the 2016 Cincinnati International turner syndrome meeting. Eu J Endocrinol. 2017;177(3):G1-G70.

7. Wolff DJ, van Dyke DL, Powell CM. Laboratory guideline for turner syndrome. Genet Med. 2010;12(1):52-5.

8. Knudtzon J, Aarskog D. 45,X/46,XY mosaicism - a clinical review and report of ten cases. Eu J Pediatr. 1987;146(3):266-71.

9. Schoemaker MJ, Swerdlow AJ, Higgins CD, Wright AF, Jacobs PA. Cancer incidence in women with turner syndrome in Great Britain: a national cohort study. The Lancet Oncol. 2008;9(3):239-46.

10. Klein KO, Rosenfield RL, Santen RJ. Estrogen replacement in turner syndrome: literature review and practical considerations. The J Clin Endocrinol Metabol. 2018;103(5):1790-803.

11. Telvi L, Lebbar A, Del Pino O, Barbet JP, Chaussain JL. 45,X/46,XY mosaicism: report of 27 cases. Pediatr. 1999;104(2):304-8.

12. Bardeguez AD, de Ziegler D, Weiss G. Multifetal pregnancy in a gonadal dysgenesis mosaic. Obstet Gynecol. 1990;76(3):502-4.

13. Scherer G, Held M, Erdel M. Three novel SRY mutations in XY gonadal dysgenesis and the enigma of XY gonadal dysgenesis cases without SRY mutations. Cytogen Gen Res. 1998;80(1):188-92.

14. Sauer MV, Lobo RA, Paulson RJ. Successful twin pregnancy after embryo donation to a patient with XY gonadal dysgenesis. Am J Obstet Gynecol. 1995;161(2):380-6.

Cite this article as: Balsarkar GD, Dalmia RD, Raut NN. Reproductive potential in a case of Mosaic Turners syndrome with 46XY karyotype. Int J Reprod Contracept Obstet Gynecol 2020;9:424-6. 